\section{Whale Conservation}

SiR,-You draw welcome attention to the fact that, notwithstanding recent concern about the effects of pollutants like DDT and others on various species of animals, the direct effects of too intensive killing have been the major cause of the observed declines in species of birds, whales or fish, and that more emphasis should be given to the studies of those direct effects (Nature, 233, 79 ; 1971). However, in doing so, you appear not to be aware of much of the work and progress that has already been achieved. As scientists who have been associated with the work of various international commissions both before and since joining FAO, we should like to make some personal observations.

We would in particular like to comment on the statements regarding Antarctic whales (see also Nature, 232, 80 ; 1971). It is certainly not true that at least two species of whale have been made extinct in the Antarctic, or indeed anywhere in the world, since the Atlantic grey whale was exterminated many centuries ago. The blue whale might have been exterminated if the slaughter of the early postwar period had continued, but since being protected in 1965 it has almost certainly increased, and now numbers several thousands-not between 100 and 1,000 as stated-and is regularly seen by whalers and research ships in the Antarctic and elsewhere.

While the International Whaling Commission has become a favourite and easy target of attacks, these criticisms do not do full justice to the commission's record in the last six years. While around 1965 the IWC was failing badly to bring the catches down into line with the figures recommended by the scientists, the catches were some three or more times the sustainable yield, and various stocks had declined seriously, the quotas now set by the IWC have been cut to a fraction of these former levels, and according to some scientists are below the sustainable yield of the stocks. The result is that, apart from the species which are fully protected, and perhaps with the exception of some local stocks of other species, the fin whale is the only species of which the present stock size is far below the level giving the maximum sustainable yield. The present Antarctic quotas are above some estimates of the current sustainable yield, though the excess is small, and if these estimates are correct the quotas would lead to only a slow further decline on the stocks.

Admittedly, much remains to be done, and in particular the member countries of the IWC are still failing to implement the international observer scheme, and little or nothing is being done to rebuild the Antarctic fin whale stocks to a level where they can provide a high sustained yield-maintaining them at around the present level is not good enough. Furthermore, problems have arisen from whaling carried out by countries not members of the commission. For example, the 66 blue whales referred to as being killed in 1967, after full protection was given to them, were killed by vessels of countries not belonging to the IWC and over which the member states of IWC had no authority, and certainly some action needs to be taken to cope with this kind of problem.

As regards fish in the North Atlantic, considerable efforts have been made within the framework of the International Commission for the North West Atlantic Fisheries and the North East Atlantic Fisheries Commission to set up international controls of the intensity of fishing in the North Atlantic, including a special meeting of NEAFC at ministerial level in Moscow last December. Progress is indeed slow, but, contrary to the impression given in your journal, limits have been set by ICNAF to the intensity of fishing on haddock in several parts of the North West Atlantic, including the Scotia Bank.

Like the IWC, these and other international bodies concerned with management and conservation of living marine resources need better support so that they can improve their performance, and particularly the speed with which they can react to the rapid changes in modern fisheries. Such support should include better facilities for the collection and analysis of information regarding the stocks, and greater authority to ensure compliance with necessary conservation action.

\section{Yours faithfully,}

L. K. BOEREMA

J. A. Gulland

Department of Fisheries,

FAO, Rome

\section{Geological Abstracts}

SIR,-Joel Lloyd (Nature, 235, 347 ; 1972) has tidied up some errors of fact in your original comment on this matter, and then gone on to add some unsubstantiated comments of his own. Since the division of opinion between us is deep and is relevant to the current urge to mechanize bibliographic services in other fields, I hope you will allow me to reply.

I do not quarrel with the suggestion that the American Geological Institute is providing a fairly comprehensive service, and that in the context of high machine costs it is wise to restrict itself to citations and not fill its magnetic tapes with abstracts. I agree that the abandoned USGS services were cheaper than they need have been, but as a run. on print from a bibliographic service paid for and justified by the internal needs of the USGS, their marginal cost was never very high. In any case, the price for his own service is also "unrealistic" and incapable of covering its costs at the present price-tag or any other, higher or lower. As in many subjects, the value placed on information does not cover the costs of the complex systems that information specialists dream up these days. Why is it that the consumers are at fault in being reluctant to pay-why cannot the information industry realize that a less sophisticated system that can cover its costs is an alternative worth considering seriously? Comparison with the costs of other more advanced and information-conscious subject fields is irrelevant; services for geologists are only going to be paid for by geologists.

To Dr Lloyd the fact that a service is not comprehensive (that is, subjectwide) and not machine-based destroys all its claims to be a useful service. The fact is that Dr Howie and I can outsell Dr Lloyd just because we each produce (very different) services that people find useful and that people do afford to buy. In time such services may grow and provide a more comprehensive service, and they will gradually become more mechanized as the users find they need more sophisticated services. Last year Geo. Abstracts spent an appreciable sum of money translating and publishing abstracts of the Russian literature, normally very inadequately covered by us. To information specialists this was an obvious and overdue extension of our service. The experiment produced two letters in favour (one of these from another bibliographer hardly counts); the remainder were strongly against. The consumer view was clear; why clutter up the Abstracts with this material we don't want ? Professionally I deplore the attitude, but are we right to burden our consumers with expensive services they do not want? It seems to me that this is a central question as expensive and heavily subsidized services bemoan the lack of consumer 
demand. Is this entirely the consumer's fault ?

Yours faithfully,

\section{K. M. Clayton}

School of Environmental Sciences, University of East Anglia,

University Village,

Norwich NOR $88 C$

\section{Forensic Science}

SIR,-Dr Curry in his article on "Recent Developments in Forensic Science" (Nature, 235, 369 ; 1971) errs on the side of extreme conservatism when he asserts that the existing techniques of blood grouping and enzyme measurement can occasionally give a discriminatory power of 1 in 1,000 . This laboratory uses routinely in case-work three serological systems (ABO; $\mathrm{MN}$; $\mathrm{Rh}$ ) and up to six enzyme systems (AK; ADA; PGM; 6PGD; G6PD; PCE) plus haptoglobin and haemoglobin. Discrimination of 1 in 1,000 is commonly obtained but from time to time values as high as 1 in $10^{6}$ have arisen.

Dr Curry has apparently overlooked the advantages of atomic absorption spectrometry which are being exploited in several forensic laboratories. Considerable developments are also being made in scanning electron microscopy particularly in conjunction with electron probe X-ray microanalysis. Such equipment has been in use in the MP Laboratory for nearly a year and has been very useful in the elemental analysis of fragments of paint, glass and metals even when the cross section of the sample analysed is as small as $10 \mu \mathrm{m}$.

Yours faithfully,

\section{R. L. WILliamS}

\section{Director}

The Metropolitan Police

Forensic Science Laboratory,

2 Richbell Place, London WCI

\section{Obituary}

\section{Sir Frederick C. Bawden}

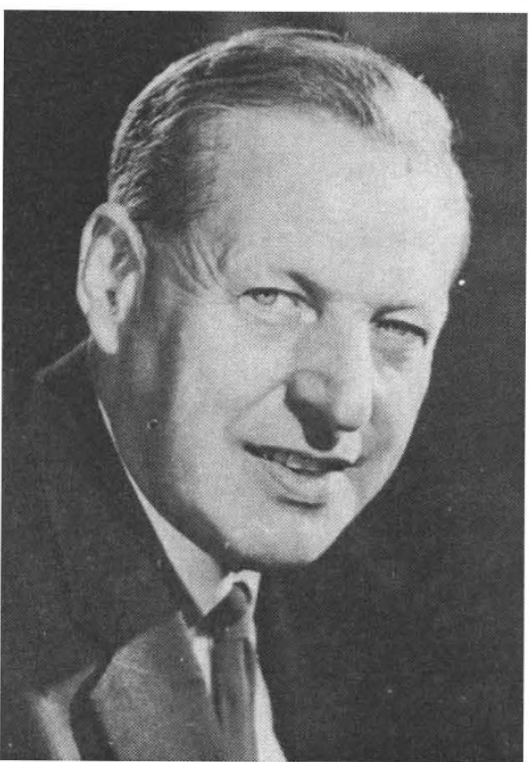

Sir Frederick Charles Bawden, FRS, Director of Rothamsted Experimental Station and Treasurer of the Royal Society, died on February 8 at the age of 63 .

Frederick Bawden was a scholar of Emmanuel College, Cambridge, and he graduated with first-class honours in botany. Rather than enrol for a PhD -a degree he never did acquireBawden instead obtained a diploma in plant pathology at the Cambridge School of Agriculture. His first appointment in 1930 was as research assistant to the formidable Redcliffe N. Salaman. Salaman, the son of a wealthy Jewish family and a medical man, was originally engaged in medical research at the London Hospital, but he contracted tuberculosis at the age of 30 and was advised to lead an outdoor existence. Living quite near Cambridge at Barley, Salaman became interested in the scien- tific genetics and breeding of the potato, on which he became a leading authority, and subsequently he developed an interest in the virus diseases of potatoes. As a consequence he persuaded the Ministry of Agriculture in 1927 to establish and finance the Potato Virus Research Station (later to become the ARC Virus Research Unit), which was situated on the edge of Cambridge University Farm, and at the time consisted only of a few glasshouses and a potato shed. There Bawden was to meet Salaman's other colleagues, who included Kenneth Smith, the station's entomologist, and to receive a thorough grounding in virus diagnosis and transmission by grafting, sap inoculation and insect transfer. The work of a research assistant consisted very largely of routine work of this type and of recording the results, often photographically, under the most primitive conditions. The darkroom was built onto the potato shed and was hot in summer and freezing in winter. There Bawden was to make his only contribution to scientific photography. Taking advantage of the infrared reflexion band of chlorophyll, he managed to get good photographs of necrotic virus symptoms on plant leaves using infrared plates ${ }^{1}$

Subsequently he became interested in the diagnosis of virus diseases using the immunological methods that had just been developed. This resulted in a fruitful collaboration with E. T. C. Spooner of Cambridge University Pathology Laboratory. Intrigued as to the nature of the viral antigens present in diseased plants, Bawden also became a close collaborator with a young biochemist, N. W. Pirie, who was Demonstrator in Sir Frederick Gowland Hopkins's famous biochemistry laboratory. Bawden and Pirie, who complemented each other in their knowledge and abilities, soon found that the antigen of Kenneth Smith's potato " $X$ " virus had many of the properties characteristic of proteins ${ }^{2}$.

At about this time W. M. Stanley at the Rockefeller Institute, Princeton, published his famous paper on the nature of the tobacco mosaic virus, making the claim that the virus was a crystalline globulin ${ }^{3}$. Repeating this work Bawden and Pirie, in collaboration with J. D. Bernal and I. Fankuchen, showed that the tobacco mosaic virus was a long thin nucleoprotein rod at least $1000 \AA$ long, having a regular structural repeat along its length every $3 \times 22 \AA$ and containing about 5 per cent of ribonucleic acid". The "crystals" of Stanley were found to be liquid crystals. This one paper more or less established modern biochemical virology as well as forming one of the foundations of molecular biology. It was followed by a monumental paper in the Proceedings of the Royal Society, which contained so much new information that even now it is well worth consulting ${ }^{5}$. In particular they noted at this time that the nucleic acid of the virus was a much larger molecule than was expected on the basis of the chemical evidence available.

The presence of nucleic acid in the virus was a matter of some controversy for some time, but Bawden and Pirie went on to purify potato " $X$ " virus, cucumber viruses 3 and 4 and Kenneth Smith's tomato bushy stunt virus, all of which were found to contain ribonucleic acid. The cucumber viruses proved unexpectedly to resemble tobacco mosaic virus both physically and chemically though they had no known host in common with the latter. This was the first instance in which virus relationships were finally recognized on the basis of chemical and 